\title{
The Opinions of Preschool Teachers Regarding the Values of Turkish Children and Syrian Refugee Children
}

\author{
Ayşe Duran Yilmaz ${ }^{1} \&$ Esra Ömeroğlu ${ }^{2}$ \\ ${ }^{1}$ Faculty of Education, Adiyaman University, Adiyaman, Turkey \\ ${ }^{2}$ Gazi Faculty of Education, Gazi University, Ankara, Turkey \\ Correspondence: Ayșe Duran Yilmaz, Faculty of Education, Adiyaman University, Adiyaman, Turkey, E-mail: \\ aduran@adiyaman.edu.tr
}

Received: March 31, 2021

Accepted: May 1, $2021 \quad$ Online Published: July 30, 2021

doi:10.5539/ies.v14n8p84

URL: https://doi.org/10.5539/ies.v14n8p84

\begin{abstract}
The purpose of the study is to determine the opinions of preschool teachers regarding the values of Turkish children and Syrian refugee children. Phenomenology design, one of the qualitative research methods, was used in this study. The study group of the research consisted of twenty-four pre-school teachers working in different cities, namely Adıyaman, Kilis, Şanlıurfa, Gaziantep, and Hatay, where refugees live intensely. Purposeful sampling method was used to determine the participants of the study. The data of the study were obtained by using semi-structured interview form. The analysis of the data of the research was made by deductive content analysis. The findings of this research reveal that Turkish children and Syrian children generally show similarities behaviors according to the values of respect, responsibility, cooperation, friendship, and helpfulness. In addition, it has been stated that Turkish children and Syrian children display negative behaviors according to the values of self-control and tolerance.
\end{abstract}

Keywords: social values, preschool teachers, preschool education, refugee children

\section{Introduction}

It is observed that there has been an increase in the number of refugees around the world due to reasons such as violation of fundamental human rights, discrimination, economic problems, natural disasters, and war. This increase in the number of refugees has started to create serious problems such as housing, health, social cohesion, and education in many countries. Refugees have to leave their countries and try to reestablish their lives in different countries. Syria is one of the countries where many people have become refugees due to the war in their country. Turkey is among the countries that come with intense migration of Syrian refugees. According to the report of The Directorate General of Migration Management of Turkey (September, 2020) 3 million 621 thousand 968 people as refugees are in Turkey. One million 664 thousand 249 of these are children between the ages of 0-18. Refugee children face serious problems in the country of migration. This situation puts refugee children at a disadvantage (Ereş, 2015). Nutrition, sheltering, and health are serious problems for refugee children. In addition, interrupting or not starting their education life is the most important problem they face (Duman \& Snoubar, 2017). Early intervention education programs could be come up with a solution for problems of refugee children. Therefore, the participation of these children to education in the receiving country is essential (Bulut, 2015).

Schools provide an excellent environment for the development of refugee children (Ingleby \& Watters, 2002). At the same time, schools are one of the important places where refugee children communicate with the community of receiving country (Tadesse, Hoot, \& Watson-Thomspon, 2009). According to results of research, refugee children have emotional and behavioral problems (Aghajafari et al., 2020; Betawi, 2019). It is therefore very important that refugee children benefit from schools so that they can adapt healthily to the society they migrate to. Lunneblad (2017) stated that preschool education institutions are supportive of refugee children.

A tolerance education environment should be provided for refugee children to benefit from preschool education institutions. It is important that both teachers and other children are respectful and lovers to accept these refugee children. This is the way the education environment is generally dependent on the knowledge, values, practices, and attitudes of teachers (Kovinthan, 2016). Teachers who have never worked with refugee children have experienced problems. It was revealed that teachers' views of refugee children were important (Maharaj-Landaeta, 
2019). Teachers who have never worked with refugee children and have not received support for their education can face some problems such as language problems, cultural problems, and behavioral problems. In his research in Gerokosta (2017), he said that preschool teachers are demonstrating a positive attitude toward refugee children adapting but need to be trained to support and solve problems they face. According to the literature, it was revealed that teachers had problems communicating with refugee children due to language problems, faced serious compliance issues, disciplinary issues, and cultural problems (Busch et al., 2018; Jennifer, Medici, Stewart, \& Cohen, 2011; Kiremit, Akpınar, \& Akcan, 2018; Taşkın \& Erdemli, 2018; Uzun \& Bütün, 2016). According to the research by Alhajii (2020), preschool teachers stated that refugee children have demonstrated behavioral problems because of their arrival from a different society, culture, and environment of values. The adoption of values of refugee children and non-refugee children from different cultures can be effective in reducing such problems. Values education can be effective in teaching social values and how to behave towards to others (Franciamora, 2014).

Refugee children and other children in the community can adapt and respect each other by adopting social values. Larson (2009) indicated that social values education contributes to the ideal environment for social adaptation in schools. With social values education, children can gain the values of respect, love, responsibility, cooperation, helpfulness, kindness, and self-control that they will reflect on their behavior. These values can also be effective in adaptation of children to different cultures. Social values education can also provide a multicultural education environment for children from different cultures (Berkowitz, 2002). Moreover, it has been revealed that the values education program has a positive effect on the behaviors of preschool children (Stewart-Burrison, 2004). Therefore, social values education should be included in the classroom environments, especially with refugee children. In order to prepare a social values education program, it is important to know the current perceptions of teachers for the values that children have.

This study is important for Turkish and Syrian refugee children to adapt to each other, to benefit refugee children from educational environments and to determine early intervention programs for the education of refugee children. Considering the limitations of the studies in the related field literature to reveal the perceptions of preschool teachers regarding the values of Turkish and Syrian refugee children, this study attempted to determine the perceptions of preschool teachers about the values of Turkish and Syrian refugee children. The general purpose of this research is to examine the perceptions of preschool teachers regarding the values of Turkish and Syrian refugee children. For this purpose, answers to the following questions were sought:

1) According to preschool teachers, what are the positive behaviors of Turkish and Syrian refugee children regarding the values of "respect, responsibility, cooperation, friendship, helpfulness, courtesy, self-control and tolerance"?

2) According to preschool teachers, what are the negative behaviors of Turkish and Syrian refugee children regarding the values of "respect, responsibility, cooperation, friendship, helpfulness, courtesy, self-control and tolerance"?

\section{Method}

\subsection{Design of the Study}

The present study investigated the perceptions of preschool teachers regarding the values of Turkish and Syrian refugee children. The research was utilized phenomenology design, one of the qualitative research designs. The phenomenology design gives the participants the opportunity to describe themselves and their life experiences. In addition, researchers have the opportunity to deeply understand the common life experiences of a group of people (Alase, 2017; Creswell \& Creswell, 2017). In this study, the phenomenology design was used as it was aimed to reveal the perceptions of preschool teachers towards the values of Turkish and Syrian refugee children.

\subsection{Participants of Study}

The participants of the study consisted of 24 pre-school teachers working in different cities, namely Adiyaman, Kilis, Şanlıurfa, Gaziantep, and Hatay, where refugees live intensely. Purposeful sampling method was used to determine the participants of the study. In this method, situations that are rich in information and considered appropriate for the purpose of the research are determined as samples (Patton, 2014). For this reason, 24 preschool teachers working in five different cities where intensely Syrian refugees live were selected. The sample consisted of teachers who work in preschool, have Turkish and Syrian refugee children in their class, and who voluntarily agree to participate in the study.

13 teachers from Adiyaman participated in the study. These teachers have at least 1 and at most 8 Syrian refugee children in their classrooms. The number of Turkish children in the class is at least 8 and at most 24 . In terms of the 
total number of children, the class size consists of at least 15 and at most 25 children. 2 teachers from Kilis participated in the research. The number of Turkish children in the classes of these teachers is at least 10 and at most 12. The number of Syrian children is at least 6 and at most 21. Class size is at least 18 and at most 31.3 teachers from Şanlıurfa participated in the research. The minimum number of Turkish children in the classes of these teachers is 14 and the maximum is 23. The number of Syrian children is at least 3 and at most 4 . In terms of class size, it is at least 17 and at most 27. 5 teachers from Gaziantep participated in the research. The number of Turkish children in the classes of these teachers is at least 14 and at most 21. The number of Syrian children is at least 1 and at most 8 . The total number of children is at least 19 and at most 22. One teacher from Hatay participated in the research. The total number of children in this teacher's class is 17 , including 15 Turkish and 2 Syrian. In total, 24 teachers from five different cities participated in the research. There are 518 children in the classrooms of these teachers, 405 of them Turkish and 113 of them Syrian.

\subsection{Data Collection Tool}

In literature, it was revealed that teachers stated 'respect, responsibility, cooperation, friendship, helpfulness, kindness, self-control and tolerance' as the values that preschool children should gain (Erkuş \& Yazar, 2013; Kozikoğlu, 2018; Ogelman \& Sarıyakaya, 2015). These eight values were determined in accordance with the purpose of the study. In this study, a semi-structured interview form developed by the researchers was used as a data collection tool. For the questions to be included in the interview form, the relevant field literature was first examined. The form included different semi-structured questions for each value. There were twenty-eight questions in total, four (4) for self-control, four (4) for respect, five (5) for tolerance, two (2) for kindness, four (4) for responsibility, three (3) for cooperation, three (3) for helpfulness and three (3) for friendship value. Exemplary questions of the interview form were "how does Turkish/Syrian children react in situations of conflict with their friends?", "Do Turkish/Syrian children talk kindly with their friends?", "Do Turkish children help their Syrian refugee friends?" An expert evaluation form was created for the prepared teacher interview form. With the expert evaluation form, the experts were asked to fill in the questions in the teacher interview form according to the suitability of the stated values or not, and to make the necessary explanations in the inappropriate items. The prepared interview form was sent to a total of five experts, four of whom were preschool education specialists and one of them the field of assessment and evaluation. In line with the expert feedback, the inter-expert agreement coefficient was checked for the questions in the interview form. As a result of the statistical process, the Fleiss Kappa coefficient of the evaluations given by the experts was calculated as ( $=0.85)$. Landis and Koch (1977) stated that "there is near perfect agreement between 0.81 and 1 " regarding the obtained $\kappa$ values. Accordingly, it can be said that there is a perfect close match between experts for the interview form.

\subsection{Data Collection Process}

During the data collection process, face-to-face interviews were made with the teachers in Adiyaman city center, and phone calls were made with the other teachers. In addition, e-mail addresses were requested from the teachers. Teachers were sent a voluntary participation form and interview form, which included the purpose and ethical dimension of the research, in e-mail. Interview dates and times were determined by contacting the teachers one by one. Interviews were held on the dates determined by the teachers. Each meeting lasted approximately 30 minutes. The interviews were recorded with a voice recorder. Interviews recorded with a tape recorder within the knowledge of the participants were transcribed. Every conversation heard during the transcription of the recorded conversations was written without any correction. Codings like "T1-T24" were used for teachers.

\subsection{Data Analysis}

The analysis of the data of the research was made by deductive content analysis from qualitative data analysis. Deductive content analysis is used to test an existing theory, concept, model, or hypothesis (Kiziltepe, 2015). With deductive analysis, first themes are created, then categories and codes are determined, and matrices that are structured according to the purpose of the study are also used (Patton, 2014; Kizlltepe, 2015). In this research, firstly themes were determined. According to the purpose of the study, these are the values that Turkish and Syrian children do not differ according to the preschool teachers, the values that the children differ, and the reactions of the children according to their Turkish or Syrian friend status. Then, the categories for each theme were determined. In the determination of the categories, open-ended questions in the data collection process of the research were determinative. The question roots in each question have created categories. After the categories were determined, the answers of the interviewed teachers were listed under the related questions and the codes were revealed. While revealing the codings, all opinions answered to the research question are combined under the same code. After the codes were determined, the whole text was reviewed again and again for content analysis and the codes, categories and themes were finalized. In the process of interpreting the findings, direct quotations were 
made from the teachers' expressions and it was supported whether the obtained results were meaningful in themselves. In this way, it is aimed to increase the reliability of the research.

\subsection{Ethical Aspect of the Research}

Ethics committee approval was obtained for this research. The approval of the Social and Human Sciences Ethics Committee of Adiyaman University was given at the meeting dated 10/11/2020 and with the decision number of 2020/22. The selection of the participants was made with the criteria determined in line with the purpose of the study. Participants were given a voluntary participation form containing the purpose and scope of the research. All participants stated that they voluntarily agreed to participate.

\section{Results}

The general purpose of this research is to find out what teachers' perception of the values that children have. These perceptions obtained as a result of the content analysis of the data were presented within the framework of the sub-questions of the research.

\subsection{Teachers' Views on Positive Behaviors of Turkish and Syrian Children According to Their Values}

The findings of teachers' opinions about the positive behaviors of Turkish and Syrian children according to the values they have are presented in Table 1.

Table 1. Findings regarding the positive behaviors of Turkish and Syrian children according to their values

\begin{tabular}{|c|c|c|c|c|c|c|c|c|c|}
\hline \multirow[b]{2}{*}{ Value } & \multirow[b]{2}{*}{ Categories } & \multirow[b]{2}{*}{ Codings } & \multicolumn{2}{|c|}{$\begin{array}{l}\text { Turkish } \\
\text { children }\end{array}$} & \multicolumn{2}{|c|}{$\begin{array}{l}\text { Syrian } \\
\text { children }\end{array}$} & \multicolumn{3}{|c|}{ Difference Status } \\
\hline & & & $\mathrm{f}$ & $\%$ & $\mathrm{f}$ & $\%$ & Codings & $\mathrm{f}$ & $\%$ \\
\hline \multirow{2}{*}{ Respect } & Accepting your friends' & Yes & 16 & 15.68 & 14 & 14.58 & Yes & 10 & 41.66 \\
\hline & feelings/ideas & No & 11 & 10.78 & 9 & 9.73 & No & 14 & 58.33 \\
\hline \multirow{3}{*}{ Responsibility } & \multirow{3}{*}{$\begin{array}{l}\text { Status of fulfilling their } \\
\text { responsibilities }\end{array}$} & When the teacher gives & 15 & 14.01 & 13 & 12.62 & \multirow{3}{*}{$\begin{array}{l}\text { Yes } \\
\text { No }\end{array}$} & \multirow{3}{*}{$\begin{array}{c}6 \\
18\end{array}$} & \multirow{3}{*}{$\begin{array}{l}25 \\
75\end{array}$} \\
\hline & & According to the rules & & 8.41 & 9 & 8.73 & & & \\
\hline & & Does not fulfill & 9 & & 2 & 1.94 & & & \\
\hline \multirow{2}{*}{ Cooperation } & \multirow{2}{*}{ Collaborate } & Yes & 22 & 29.72 & 18 & 25 & Yes & 9 & 37.50 \\
\hline & & No & 4 & 5.40 & 6 & 8.33 & No & 15 & 62.50 \\
\hline \multirow{2}{*}{ Friendship } & \multirow{2}{*}{$\begin{array}{l}\text { Preferring Syrian/Turkish } \\
\text { friends in their games }\end{array}$} & Yes & 16 & 21.62 & 15 & 20.83 & \multirow{2}{*}{$\begin{array}{l}\text { Yes } \\
\text { No }\end{array}$} & 5 & \multirow{2}{*}{$\begin{array}{l}20.83 \\
79.16 \\
\end{array}$} \\
\hline & & No & 8 & 10.81 & 9 & 12.50 & & 19 & \\
\hline \multirow{5}{*}{ Helpfulness } & \multirow{2}{*}{ Help } & Yes & 24 & \multirow{2}{*}{33.33} & 22 & 30.55 & \multirow{5}{*}{$\begin{array}{l}\text { Yes } \\
\text { No }\end{array}$} & \multirow{5}{*}{$\begin{array}{c}7 \\
17\end{array}$} & \multirow{5}{*}{$\begin{array}{l}29.16 \\
70.83\end{array}$} \\
\hline & & No & - & & 2 & 2.77 & & & \\
\hline & \multirow{3}{*}{ Who do they get help from } & Everyone & 14 & 19.44 & & & & & \\
\hline & & Close friends & 7 & 9.72 & 24 & 33.33 & & & \\
\hline & & Teacher & 3 & 4.16 & & & & & \\
\hline \multirow{2}{*}{ Kindness } & \multirow{2}{*}{ Polite speech } & Yes & 20 & 37.73 & 8 & 16.66 & Yes & 8 & 33.33 \\
\hline & & No & 9 & 16.98 & 16 & 33.33 & No & 16 & 66.66 \\
\hline
\end{tabular}

Table 1 contains the findings of preschool teachers' opinions regarding the positive behaviors of Turkish and Syrian children according to the values they have. When the views on value of respect are examined, teachers stated that Turkish and Syrian children generally "accept the feelings and ideas of their friends". According to the category of "fulfilling their responsibilities" considered within the scope of the value of responsibility, it is seen that Turkish and Syrian children mostly fulfill their responsibilities "when a teacher gives them" and "according to the rules". According to the value of cooperation, teachers stated that Turkish and Syrian children generally cooperate. According to the category of "preferring Turkish or Syrian friends in their games", which is considered within the scope of friendship value, it is seen that children mostly prefer their Turkish or Syrian friends in their games. The categories of "helping" and "who are they getting help from" have emerged within the scope of helpfulness value. According to the category of helping, teachers stated that Turkish and Syrian children generally helped. When the category of "Who are they receiving assistance from" is examined, it is revealed that Turkish children get help from "everybody-teacher-close friend" and Syrian children get help from "everyone". Within the scope of courtesy value, the category of "polite speech" has been handled. According to this category, teachers stated that Turkish children mostly speak politely, but Syrian children do not. Teachers also stated that the values of respect, responsibility, cooperation, friendship, helpfulness, and kindness of children generally do not differ from 
their Turkish and Syrian friends.

T24: "They fulfill their responsibilities under my guidance... I constantly repeat the commands, telling them how to do it... they don't react when I give the responsibility, it doesn't matter if they are Turkish or Syrian ...... they react violently when they suffer injustice and sometimes, they complain to me ... Some can directly go and beat his friend. Syrian children show the same reaction ...... there is no difference in their reactions, they show the same reaction.

"T1:" Children help each other, especially in art activities, children make conscience... there is no discrimination among their friends, they help each other when help is provided... Children with leadership characteristics sometimes do not ask for help, of course. "

T3: "There is a kindly conversation between Turks and Syrians. Syrians do not have a proper and polite sentence because they are new in the language. Due to the language problem, courtesy is not much. "

T5: "They do it, they collaborate. Turks offer cooperation to their Syrian friends. Turks always add Syrians. In the first place, I experienced this problem in my classroom for a month or so when the school was opened, they were a little excluded. Then, over time, children started to accept Syrian students, and they also accept us. "

T8: "In their games, Turkish children prefer Syrians and Syrians prefer Turkish children. For example, while collecting toys, feeding, Turkish students go and share their own food with them without telling them... Syrians do not share this."

3.2 Teachers' Views on Negative Behaviors of Turkish and Syrian Children According to Their Values

The findings of teachers' opinions on the negative behaviors of Turkish and Syrian children according to their values are presented in Table 2 .

Table 2. Findings regarding the negative behaviors of Turkish and Syrian children according to their values

\begin{tabular}{|c|c|c|c|c|c|c|c|c|c|}
\hline \multirow[b]{2}{*}{ Value } & \multirow[b]{2}{*}{ Categories } & \multirow[b]{2}{*}{ Codings } & \multicolumn{2}{|c|}{$\begin{array}{l}\text { Turkish } \\
\text { Children }\end{array}$} & \multicolumn{2}{|c|}{$\begin{array}{c}\text { Syrian } \\
\text { Children }\end{array}$} & \multicolumn{3}{|c|}{ Difference Status } \\
\hline & & & $\mathrm{f}$ & $\%$ & $\mathrm{f}$ & $\%$ & Codings & $\mathrm{f}$ & $\%$ \\
\hline \multirow{9}{*}{ Self-regulation } & \multirow{3}{*}{$\begin{array}{l}\text { Their negative reaction to the conflict } \\
\text { situation }\end{array}$} & Violence & 11 & 9.16 & 13 & 11.11 & \multirow{9}{*}{$\begin{array}{l}\text { Yes } \\
\text { No }\end{array}$} & \multirow{9}{*}{$\begin{array}{l}10 \\
14\end{array}$} & \multirow{9}{*}{$\begin{array}{l}41.66 \\
58.33\end{array}$} \\
\hline & & Complaint & 9 & 7.50 & 5 & 4.27 & & & \\
\hline & & Crying & - & - & 3 & 2.56 & & & \\
\hline & \multirow{6}{*}{ Methods of dealing with negative emotions } & Violence & 10 & 9.80 & 13 & 13.54 & & & \\
\hline & & Complaint & 5 & 4.90 & 5 & 5.20 & & & \\
\hline & & Talk & 4 & 3.92 & - & - & & & \\
\hline & & Offended & 3 & 2.90 & - & - & & & \\
\hline & & Crying & 3 & 2.90 & 4 & 4.16 & & & \\
\hline & & Anger & - & & 3 & 3.12 & & & \\
\hline \multirow{6}{*}{ Tolerance } & \multirow{6}{*}{$\begin{array}{c}\text { Reactions to Negative criticism of } \\
\text { themselves }\end{array}$} & Silence & 6 & 4.76 & 6 & 4.83 & \multirow{6}{*}{$\begin{array}{l}\text { Yes } \\
\text { No }\end{array}$} & \multirow{6}{*}{$\begin{array}{c}4 \\
20\end{array}$} & \multirow{6}{*}{$\begin{array}{l}16.66 \\
83.33\end{array}$} \\
\hline & & Respect & 6 & 4.76 & - & - & & & \\
\hline & & Violence & 5 & 3.96 & 8 & 6.45 & & & \\
\hline & & Crying & 4 & 3.17 & 7 & 5.64 & & & \\
\hline & & Defend & 4 & 3.17 & - & - & & & \\
\hline & & Complaint & 3 & 3.12 & 3 & 2.41 & & & \\
\hline
\end{tabular}

When Table 2 is examined, findings regarding the negative behaviors of Turkish and Syrian children according to their values are seen. Accordingly, the value of self-control has been handled in the dimensions of "negative reactions according to the conflict situation" and "methods of dealing with negative emotions". According to the category of "negative reactions according to the conflict situation", teachers stated that Turkish and Syrian children generally resort to "violence" and "complaint" in case of conflict. When the category of "methods of dealing with negative emotions" was examined, it was found that the vast majority of Turkish and Syrian children showed "violence". Apart from this, teachers stated that Turkish children show "complaint-talk-offense-cry" and Syrians show "complaint-cry-anger". The value of tolerance has been examined in the category of "their reactions to negative criticism against themselves". According to this, teachers stated that Turkish children react to "silence-respect-violence-cry-defense and complaint" and Syrian children react to "violence-cry-silence and complaint". It has been stated that "silence and showing respect" are seen more in Turkish children and "violence 
and crying" are seen more in Syrian children. Teachers also stated that the self-control and tolerance values of children generally do not differ according to their Turkish and Syrian friends.

T11: "If the children understand the criticism, they either cry or get upset or come and complain to me. There is also a general thing among Syrian students, either they turn to him and get angry or beat him, or he does not say anything... When the Turkish child criticizes the Syrian; here they fight him, they beat him. Syrians frankly fight a lot. They beat them too much, either they are too with drawn or they beat too much. If the Syrian criticizes, the Turk will come and complain to me immediately, but the Turks also have fights, something is happening with the child, if they have trouble ...... When their friends make a mistake, they come to me and speak. They complain that my teacher! he/she did it like that or something. There are too many complaints..."

T2: "The first reaction of the Syrians when there is a conflict is hitting the Turks, but the Turkish children shout at the Syrians. They try to deal with the conflict between the Turks by talking to each other. If the children cannot solve their problems, they come to me. Among the Syrian children, passive children come to me and complain like "teacher! teacher!"

T6: "Usually there are hitting, violent things. There is a hitting immediately, so there is nothing like expressing it or telling someone. For example, I had a problem with you, I hit you immediately ......... They accept the opinions of their friends. They also accept the ideas of Syrian children, they actually like it very much, the Turkish perspective on them is really nice, but they are a little different ...... When his friend does something different, they get involved in him, the children do not cause trouble. They even like to be involved ...... They get into their game with the Syrian child, and he gets into their game. We have no problem with that."

\section{Discussion, Conclusion and Recommendations}

As a result of this study, which examined pre-school teachers 'perceptions of the values of Turkish and Syrian children, two main themes emerged, namely, teachers' opinions regarding the positive and negative behaviors of Turkish and Syrian children according to their values.

When the results regarding the positive behaviors of children according to their values are examined, teachers stated that Turkish and Syrian children generally show similarities in respect, responsibility, cooperation, friendship, and helpfulness values. In this context, it has been revealed that children accept the feelings and ideas of their friends, fulfill their responsibilities, cooperate, prefer their Turkish and Syrian friends in their games and help them. However, teachers also stated that the values of respect, responsibility, cooperation, friendship, helpfulness, and kindness that children have are generally similar to their Turkish and Syrian friends. Çiçekoğlu, Durualp, and Kadan (2019) compared the peer relationships of refugee and non-refugee children in the preschool period, and researchers were stated that refugee and non-refugee children were at a similar level in social behavior for aid purposes. Gaias, Gal, Abry, Taylor, and Granger (2018), on the other hand, found that children who were educated with people from different cultures in preschool classrooms were more successful in making friends with their different peers as a result of their research. In addition, as a result of the study in which Bouillet and Miskeljin (2017) examined the effect of the education model of respect for differences in the preschool period, it was revealed that children were willing to communicate with other children with different characteristics and identities and they respect each other. Accordingly, it can be said that Turkish and Syrian children from different cultures receive education in the same classroom environment in the preschool period has a positive effect on the values of solidarity, friendship, respect, responsibility, and cooperation. Looking at the results regarding the value of courtesy, it was revealed that Turkish children generally speak politely, but Syrian children do not. Yanık-Özger and Akansel (2019) revealed that the language problem is an important factor as a result of their research examining the peer culture in the preschool education environment with Syrian children. It was stated that Syrian children's Turkish knowledge level is effective in learning classroom rules and communicating with other children. In addition, as a result of the study conducted by Uzun and Bütün (2016), it was revealed that Syrian refugee children in preschool education institutions had serious problems with their teachers and peers because they do not speak Turkish. In this context, it can be achieved that speaking the same language in the classroom environment can be achieved in the kindness of children from different cultures towards each other. However, it can be thought that the language problem is an obstacle for Syrian refugee children to express themselves.

According to the self-control value of the children, teachers stated that Turkish and Syrian children generally resorted to violence and complained about their friends. Aydoğan and Özyürek (2013) found that preschool teachers stated that parents' attitudes and violent programs on TV were the causes of violent behavior in children in their classrooms. Winslow and Shaw (2007) found that preschool children living in disadvantaged areas are more likely to display violent behaviors. Participants of the study, teachers defined the neighborhoods where their schools are located as disadvantageous. Therefore, both Turkish and Syrian children showing violence within the 
scope of their self-control value can be explained by the conditions of the disadvantaged region they live in, the attitudes of their parents and the programs containing violence on TV. According to the value of tolerance, it has been revealed that Turkish children generally show "silence and respect", and Syrian children show "violence and silence". Research has revealed that refugee children show high levels of emotional and behavioral problems (Bronstein \& Montgomery, 2011). The fact that Syrian children resort to violence when criticized by their friends can be explained by the emotional and behavioral problems experienced as a result of being a refugee.

As a result, preschool teachers stated that Turkish and Syrian children display positive behaviors according to the values of respect, responsibility, cooperation, friendship, and helpfulness. According to the value of kindness, while Turkish children also display positive behavior, it has been revealed that Syrian children do not have positive behaviors because they cannot speak Turkish. It has been stated that Turkish and Syrian children display negative behaviors according to the values of self-control and tolerance.

According to the results obtained from the research, it is possible to offer some suggestions to preschool teachers. Teachers can include group activities for Turkish and Syrian children to address the values of cooperation, friendship, responsibility, and helpfulness. They can organize activities aimed at different cultures and activities to respect differences in the classroom in order to respect their values. Teachers can inform parents about the TV programs, videos, and internet games the children watch on the conflict situation and methods of dealing with negative emotions. Coping with conflict situations and negative emotions can also prevent children from showing violence through family involvement in this way. Individual education programs can be applied to refugee children on language problems. In this way, teachers can help refugee children express themselves. By supporting the classroom environment with visuals featuring different cultures, they can raise the awareness of children about respect for differences.

\section{References}

Aghajafari, F., Pianorosa, E., Premji, Z., Souri, S., \& Dewey, D. (2020). Academic achievement and psychosocial adjustment in child refugees: A systematic review. Journal of Traumatic Stress, 33(6), 908-916. https://doi.org/10.1002/jts.22582

Alase, A. (2017). The Interpretative Phenomenological Analysis (IPA): A Guide to a Good Qualitative Research Approach. International Journal of Education and Literacy Studies, 5(2), 9-19. https://doi.org/10.7575/aiac.ijels.v.5n.2p.9

Alhajji, Y. (2020). Early childhood education of refugee students in Lebanon: Teachers' perspectives (Unpublished master's thesis). University of Jyvaskyla, Finland.

Aydoğan, Y., \& Özyürek, A. (2013). Okul öncesi çocuklarda şiddet davranışları. Uluslararası Aile Çocuk Eğitimci Dergisi, 1(2), 1-18. https://doi.org/10.36731/cg.467662

Berkowitz, M. W. (2002). The science of character education. In W. Damon (Ed.), Bringing in a new era in character education (pp. 43-63). Stanford, CA: Hoover Institution Press.

Betawi, I. A. (2019). Away from home: Psychological well-being of Syrian children at Azraq Refugee Camp in Jordan. Early Child Development and Care, 189(5), 846-854. https://doi.org/10.1080/03004430.2017.1345895

Bouillet, D., \& Miškeljin, L. (2017). Model for developing respect for diversity at early and preschool age. Croatian Journal of Education: Hrvatski časopis za odgoj $i$ obrazovanje, 19(4), 1265-1295. https://doi.org/10.15516/cje.v19i4.2567

Bronstein, I., \& Montgomery, P. (2011). Psychological distress in refugee children: A systematic review. Clinical child and family psychology review, 14(1), 44-56. https://doi.org/10.1007/s10567-010-0081-0

Bulut, Y. (Ed.) (2015). Uluslararası gö̧ ve mülteci uyumu sorununda kamu yönetiminin rolü [The role of public administration in the problem of international migration and refugee integration]. Kocaeli: Umuttepe Publications.

Busch, J., Bihler, L. M., Lembcke, H., Buchmüller, T., Diers, K., \& Leyendecker, B. (2018). Challenges and solutions perceived by educators in an early childcare program for refugee children. Frontiers in Psychology, 9, 1621. https://doi.org/10.3389/fpsyg.2018.01621

Çiçekoğlu, P., Durualp, E., \& Kadan, G. (2019). Investigation of peer relations of preschool refugee and non-refugee children. Archives of Psychiatric Nursing, 33(4), 319-324. https://doi.org/10.1016/j.apnu.2019.01.004 
Creswell, J. W., \& Creswell, J. D. (2017). Research design: Qualitative, quantitative, and mixed methods approach. Sage publications.

Duman, N., \& Snoubar, Y. (2017). Role of Social Work in the Integrating Refugee and Immigrant Children into Schools. European Journal of Social Science Education and Research, 4(4), 334-344. https://doi.org/10.26417/ejser.v10i2.p294-294

Ereş, F. (2015). Türkiye'de göçmen eğitimi sorunsalı ve göçmen eğitiminde farklılığın yönetimi. Çankırı Karatekin Üniversitesi Sosyal Bilimler Enstitüsü Dergisi, 6(2), 17-30.

Erkuş, S., \& Yazar, T. (2013). Okul Öncesi Öğretmenlerinin Okul Öncesi Eğitim Programindaki Değerler Eğitimine İlişkin Görüşlerinin Değerlendirilmesi. Dicle Üniversitesi Ziya Gökalp Eğitim Fakültesi Dergisi, 20, 196-211.

Franciamore, N. O. (2014). Parent Perceptions of Character Education in Universal Pre-Kindergarten (Unpublished doctoral dissertation). Walden University, Washington, USA.

Gaias, L. M., Gal, D. E., Abry, T., Taylor, M., \& Granger, K. L. (2018). Diversity exposure in preschool: Longitudinal implications for cross-race friendships and racial bias. Journal of Applied Developmental Psychology, 59, 5-15. https://doi.org/10.1016/j.appdev.2018.02.005

Gerokosta, V. S. (2017). Integration of refugee children in kindergarten views of nursery teachers in the prefecture of Chios. Journal of Contemporary Education, Theory \& Research, 1(1), 33-40.

Ingleby, D., \& Watters, C. (2002). Refugee children at school: good practices in mental health and social care. Education and Health, 20(3), 43-45.

Jennifer, J. H., Medici, A., Stewart, E., \& Cohen, Z. (2011). Supporting preschoolers and their families who are recently resettled refugees. Multicultural Perspectives, 13(3), 160-166. https://doi.org/10.1080/15210960.2011.594400

Kiremit, R. F., Akpınar, Ü., \& Akcan, A. T. (2018). Suriyeli öğrencilerin okula uyumları hakkında öğretmen görüşleri. Kastamonu Ĕgitim Dergisi, 26(6), 2139-2149.

Kızıltepe, Z. (2015). İçerik Analizi. Nitel araştırma yöntem, teknik, analiz ve yaklaşımlar (Ed: Fatma Nevra Seggie ve Yasemin Bayyurt). Ankara: Anı Yayıncılık.

Kovinthan, T. (2016). Learning and teaching with loss: Meeting the needs of refugee children through narrative inquiry. Diaspora, Indigenous, and Minority Education, 10(3), 141-155. https://doi.org/10.1080/15595692.2015.1137282

Kozikoğlu, İ. (2018). Okul öncesi öğretmenlerinin değerler eğitimine ilişkin tutum ve görüşlerinin incelenmesi. Uluslararası Türkçe Edebiyat Kültür Eğitim (TEKE) Dergisi, 7(4), 2698-2720. https://doi.org/10.7884/teke.4333

Larson, K. (2009). Understanding the importance of character education (Unpublished doctoral dissertation). Wisconsin-Stout University, USA.

Lunneblad, J. (2017). Integration of refugee children and their families in the Swedish preschool: Strategies, objectives, and standards. European Early Childhood Education Research Journal, 25(3), 359-369. https://doi.org/10.1080/1350293X.2017.1308162

Maharaj-Landaeta, S. (2019). The educational experiences of teachers who deal with children of refugees, asylum seekers and migrant children on the move in Trinidad \& Tobago. West East Journal of Social Sciences, 8(3), 270-282. https://doi.org/10.36739/wejss.2019.v8.i3.33

Ogelman, H. G., \& Sarikaya, H. (2015). Okul öncesi eğitimi öğretmenlerinin değerler eğitimi konusundaki görüşleri: Denizli ili örneği. Sakarya Üniversitesi Eğitim Fakültesi Dergisi, 29, 81-100.

Özger, B. Y., \& Akansel, A. (2019). Okul Öncesi Sınıfındaki Suriyeli Çocuklar ve Aileleri Üzerine Bir Etnografik Durum Çalışması: Bu Sınıfta Biz De Varız! Eğitimde Nitel Araştırmalar Dergisi, 7(3), 942-966. https://doi.org/10.14689/issn.2148-624.1.7c.3s.3m

Patton, M. Q. (2014). Qualitative research \& evaluation methods: Integrating theory and practice. Sage publications.

Stewart-Burrison, L. (2014). Effect of character education on student behavior in kindergarten (Unpublished doctoral dissertation). Walden University, Washington, USA.

Tadesse, S., Hoot, J., \& Watson-Thompson, O. (2009). Exploring the special needs of African refugee children in 
US schools. Childhood Education, 85(6), 352-356. https://doi.org/10.1080/00094056.2009.10521400

Taskin, P., \& Erdemli, O. (2018). Education for Syrian refugees: Problems faced by teachers in Turkey. Eurasian Journal of Educational Research, 18(75), 155-178.

Uzun, E. M., \& Bütün, E. (2016). Okul öncesi eğitim kurumlarındaki Suriyeli sığınmacı çocukların karşılaştıkları sorunlar hakkında öğretmen görüşleri. Uluslararası Erken Çocukluk Eğitimi Çalışmaları Dergisi, 1(1).

Winslow, E. B., \& Shaw, D. S. (2007). Impact of neighborhood disadvantage on overt behavior problems during early childhood. Aggressive Behavior: Official Journal of the International Society for Research on Aggression, 33(3), 207-219. https://doi.org/10.1002/ab.20178

\section{Copyrights}

Copyright for this article is retained by the author(s), with first publication rights granted to the journal.

This is an open-access article distributed under the terms and conditions of the Creative Commons Attribution license (http://creativecommons.org/licenses/by/4.0/). 